\title{
Pemicu Tindakan Terorisme di Kabupaten Lamongan
}

\author{
Mohammad Sirojuddin \\ Institute Agama Islam Qomaruddin Gresik \\ sirojuddin45@gmail.com
}

\begin{abstract}
One of the problems that continues to emerge in the Indonesian public sphere is religious intolerance, radicalization and terrorism. Religious intolerance, radicalization and terrorism are manifested in the prohibition of religious worship activities, the spread of hatred, religious based violence or the destruction of places of worship. In addition to increasingly diverse forms of intolerance, the area is also expanding. Early studies show that there is a strong geographical link between the growth of religious intolerance and the recruitment of terrorist groups and ISIS. Religious intolerance has occurred in almost all regions of Indonesia, as well as the radicalization of religion and terrorism. The purpose of this research is to provide an adequate and strong explanation related to the nature and causes of intolerance, radicalism and terrorism in Indonesia. This research specifically wants to find out more clearly and in depth about why and how some Indonesians have a tendency to turn into intolerance and radicals, or on the other hand, why and how some others can maintain the values of tolerance.
\end{abstract}

Keywords: Radicalism, Terrorism, Lamongan 


\section{Pendahuluan}

Indonesia dalam rentang waktu 10 tahun ini mengindikasikan adanya gejala intoleransi, radikalisme dan terorisme. Terorisme, penyerangan dan pengusiran terhadap kelompok minoritas, pelarangan kegiatan, dan pembakaran buku adalah sebagian bentuk intoleransi dan radikalisme itu. Indonesia masih menyimpan potensi intoleransi dan radikalisme, sebagian dari itu sudah terjadi meski hanya di beberapa daerah, sebagian besarnya bukan tidak mungkin akan muncul ke permukaan secara masif di waktu yang akan datang, jika tidak ditangani secara sungguh-sungguh.

Dibeberapa kampus perguruan tinggi umum, kecenderungan mahasiswa untuk mendukung tindakan radikalisme juga sangat tinggi. Hal ini terungkap dalam penelitian tentang Islam Kampus yang melibatkan 2466 sampel mahasiswa dari berbagai perguruan tinggi ternama di Indonesia. Ketika para mahasiswa ditanya tentang pelaksanaan amar makruf nahi munkar dalam bentuk sweeping tempat-tempat yang dianggap sumber maksiyat, mereka menjawab sebagai berikut: sekitar 65\% (1594 responden) mendukung dilaksanakannya sweeping kemaksiyatan, $\quad 18 \% \quad$ (446 responden) mendukung sekaligus berpartisipasi aktif dalam kegiatan sweeping. Selanjutnya, mereka yang mendukung sweeping beralasan bahwa kegiatan sweeping tersebut sebagai bagian dari perintah agama (88\%), mendukung sweeping karena berpendapat bahwa aparat keamanan tidak mampu menegakkan hukum (4\%), dan karena alasan dekadensi moral (8\%) (Fadjar, 2007 : 35).

Fenomena kekerasan atas nama agama yang sering dikenal dengan radikalisme agama semakin tampak garang ketika muncul berbagai peristiwa teror pemboman di tanah air. Beberapa peristiwa teror dalam bentuk pengeboman telah memakan banyak korban dan berdampak luas terhadap kehidupan sosial masyarakat Indonesia. Setidaknya telah terjadi lebih dari 20 kali peristiwa pemboman sejak tahun 2000 sampai sekarang (Wikipedia, 2017). Jaringan terorisme terus bekerja dan perekrutan orang baru untuk menjalankan aksi teror masih berlangsung, meski tokoh-tokoh utama pelaku teror sudah ditahan. Hal ini sejalan dengan temuan Wahid Foundation dalam laporannya tahun 2014, ditemukan bahwa dari 230 organisasi yang telah berdiri sejak zaman Orde Lama, 147 diidentifikasi sebagai organisasi intoleran, 49 organisasi 
memiliki kecenderungan pada radikalisme, dan 34 organisasi terindikasi sebagai kelompok terror.

Penelitian ini mengambil lokasi di Lamongan karena kota ini menyumbang banyak sekali tokoh-tokoh terorisme yang ada di Indonesia. Mengutip laporan IPAC (Institute for Policy Analysis of Conflict) soal Jaringan Lamongan, kota ini dikenal sebagai wilayah dengan sekolahsekolah agama penelur tokoh teror. Analisis yang dilakukan terhadap hubungan tokoh-tokoh di Lamongan menunjukkan jaringan alumni pesantren Al Islam dan sekolah lainnya pernah berhubungan dengan organisasi Jamaah Islamiyah. Walaupun tokoh-tokoh ini bukan atau dalam beberapa kasus, bukan lagi anggota JI, sekolah-sekolah ini tetap menjadi komponen penting untuk komunitas ekstremis setelah JI sendiri sudah berhenti, setidaknya sementara, melakukan kekerasan. Dari uraian di atas dapat di tarik permasalahan sebagai berikut: Bagaimana perilaku radikalisme bisa mengarah pada tindakan terorisme di Kabupaten Lamongan ? Bagaimana mencegah atau mengurangi perilaku radikalisme supaya tidak mengarah kepada terorisme di Kabupaten Lamongan?

\section{Toleransi Agama}

Istilah radikalisme berasal dari bahasa Latin "radix" yang artinya akar, pangkal, bagian bawah, atau bisa juga berarti menyeluruh, habis-habisan dan amat keras untuk menuntut perubahan. Menurut Kamus Besar Bahasa Indonesia (KBBI) radikalisme berarti (1) paham atau aliran yang radikal dalam politik; (2) paham atau aliran yang menginginkan perubahan atau pembaharuan sosial dan politik dengan cara kekerasan atau drastis; (3) sikap ekstrem dalam aliran politik. $^{1}$ Setidaknya, radikalisme bisa dibedakan ke dalam dua level, yaitu level pemikiran dan level aksi atau tindakan. Pada level pemikiran, radikalisme masih berupa wacana, konsep dan gagasan yang masih diperbincangkan, yang intinya mendukung penggunaan cara-cara kekerasan untuk mencapai tujuan. Adapun pada level aksi atau tindakan, radikalisme bisa berada pada ranah sosial-politik dan agama. Pada ranah politik, faham ini tampak tercermin dari adanya tindakan memaksakan pendapatnya dengan cara-cara yang inkonstitusional, bahkan bisa berupa tindakan mobilisasi masa untuk

1 Departemen Pendidikan dan Kebudayaan, (1995). Kamus Besar Bahasa Indonesia, Ed.II; Jakarta: Balai Pustaka,hlm. 115 
kepentingan politik tertentu dan berujung pada konflik sosial.

Dalam bidang keagamaan, fenomena radikalisme agama tercermin dari tindakan-tindakan destruktifanarkis atas nama agama dari sekelompok orang terhadap kelompok pemeluk agama lain (eksternal) atau kelompok seagama (internal) yang berbeda dan dianggap sesat. Lebih detil, Rubaidi menguraikan lima ciri gerakan radikalisme. Pertama, menjadikan Islam sebagai ideologi final dalam mengatur kehidupan individual dan juga politik ketata negaraan. Kedua, nilai-nilai Islam yang dianut mengadopsi sumbernya di Timur Tengah secara apa adanya tanpa mempertimbangkan perkembangan sosial dan politik ketika Al-Quran dan hadits hadir di muka bumi ini, dengan realitas lokal kekinian. Ketiga, karena perhatian lebih terfokus pada teks AlQur'an dan hadist, maka purifikasi ini sangat berhati-hati untuk menerima segala budaya non asal Islam (budaya Timur Tengah) termasuk berhati-hati menerima tradisi lokal karena khawatir mencampuri Islam dengan bid'ah. Keempat, menolak ideologi Non-Timur Tengah termasuk ideologi Barat, seperti demokrasi, sekularisme dan liberalisme. Kelima, gerakan kelompok ini sering berseberangan dengan masyarakat luas termasuk pemerintah. Oleh karena itu, terkadang terjadi gesekan ideologis bahkan fisik dengan kelompok lain, termasuk pemerintah. ${ }^{2}$

Menurut Simon Tormey dalam International Enyclopedia of Social Sciences (Vol.7, hal 48), radikalisme merupakan sebuah konsep yang bersifat kontekstual dan posisional, dalam hal ini kehadirannya merupakan antitesis dari ortodoks atau arus utama (mainstream), baik bersifat sosial, sekuler, saintifik, maupun keagamaan. Menurutnya, radikalisme tidak mengandung seperangkat gagasan dan argumen, melainkan lebih memuat posisi dan ideologi yang mempersoalkan atau menggugat sesuatu (atau segala sesuatu) yang dianggap mapan, diterima, atau menjadi pandangan umum. ${ }^{3}$ Radikalisme adalah paham atau aliran yang menginginkan perubahan atau pembaharuan sosial dan politik dengan cara kekerasan atau drastis. Sedangkan Kelompok Islam radikal adalah sebuah gerakan politik ekstrim yang berusaha membentuk negara Islam melalui

\footnotetext{
${ }^{2}$ A. Rubaidi, Radikalisme Islam, Nahdlatul Ulama; Masa Depan Moderatisme Islam di Indonesia, (Yogykarta: Logung Pustaka, 2010), hlm. 63

3 Azca, Muhammad Najib. Yang Muda, Yang Radikal: Refleksi Sosiologis Terhadap Fenomena Radikalisme Kaum Muda Muslim di Indonesia Pasca Orde Baru. Jurnal Maarif, Vol. 8, No. 1 (Juli 2013): 14-41.
} 
perjuangan bersenjata. Dimana terdapat doktrin-doktrin pada kelompok untuk membenarkan tindakan kekerasan untuk menghilangkan rezim di dunia yang dianggap kafir saat ini. Dan karena tindakan kekerasan inilah, maka gerakan Islam radikal seringkali di cap sebagai teroris oleh negara-negara barat khususnya Amerika. ${ }^{4}$

Radikalisasi adalah proses perubahan di mana kelompok mengalami transformasi ideologi atau perilaku yang mengarah pada penolakan prinsipprinsip demokrasi dengan cara menuntut untuk dilakukannya revolusi di bidang sosial politik, sosial ekonomi, dan perubahan budaya dengan jalan kekerasan atau peningkatan tingkat kekerasan, untuk mencapai tujuan politik. Pada dasarnya radikalisasi muncul akibat adanya kesenjangan dan marjinalisasi politik. Adapun tujuan dari kelompok-kelompok radikal di indonesia adalah menciptakan negara islam. Dalam mencapai tujuan, kelompok ini melakukan proses rekruitmen anggota mulai dari tingkat sekolah hingga universitas. Dan biasanya proses

\footnotetext{
4 Cavatorta, Francesco, (2005). The =War on Terrorism-Perspectives from Radical Islamic Groups. Journal of Irish Studies in International Affairs, Vol. 16 (2005). Diakses dari http://doras.dcu.ie/488/1/isia 16 April 2017.pd $\underline{\mathrm{f}}$
}

indoktrinasi ini dilakukan melalui kegiatan ekstrakurikuler agama yang ada di sekolah maupun perguruan tinggi. Ada 3 cara yang dapat ditempuh untuk menganalisis munculnya gerakan islam radikal di indonesia yakni: 1. Konteks historis; munculnya islam radikal di indonesia. 2. Konteks global; kebangkitan gerakan jihad, 3. Implementasi syariah sebagai ideologi negara. ${ }^{5}$

Radikalisme memiliki istilah yang beragam, ada yang menyebut radikalisme dengan istilah fundamentalisme, ada pula yang menyebutnya sebagai ekstrimisme bahkan ada pula yang mengaitkannya dengan terorisme. Penamaan ini disebabkan karena makna yang terkandung dalam istilah-istilah tersebut hampir sama. Jika radikalisme disebut sebagai paham yang cenderung menggunakan jalan kekerasan, maka istilah fundamentalisme dimaknai sebagai paham yang cenderung untuk memperjuangkan sesuatu secara radikal, selanjutnya ekstrimisme dimaknai sebagai paham yang cenderung ekstrim (keras). Selanjutnya istilah terorisme sering pula dikaitkan dengan radikalisme karena terorisme mengandung makna

\footnotetext{
${ }^{5}$ Hasan, Noorhaidi. Islam di Ruang Publik; Politik Identitas dan Masa Depan Demokrasi di Indonesia. Jakarta; Center for Study of Religion and CultureKAS, 2010.
} 
penggunaan kekerasan untuk menimbulkan rasa takut dalam usaha mencapai suatu tujuan. ${ }^{6}$

\section{Tindakan Terorisme}

Terorisme bukan persoalan siapa pelaku, kelompok dan jaringannya. Namun, lebih dari itu terorisme merupakan tindakan yang memiliki akar keyakinan, doktrin dan ideologi yang dapat menyerang kesadaran masyarakat. Tumbuh suburnya terorisme tergantung di lahan mana ia tumbuh dan berkembang. Jika ia hidup di tanah gersang, maka terorisme sulit menemukan tempat, sebaliknya jika ia hidup di lahan yang subur maka ia akan cepat berkembang. Ladang subur tersebut menurut Hendropriyono adalah masyakarat yang dicemari oleh paham fundamentalisme ekstrim atau radikalisme keagamaan. ${ }^{7}$

Radikalisme merupakan suatu sikap yang mendambakan perubahan secara total dan bersifat revolusioner dengan menjungkirbalikkan nilai-nilai yang ada secara drastis lewat kekeraan (violence) dan aksi-aksi yang ekstrem. Ada beberapa ciri yang bisa dikenali dari

6 Departemen Pendidikan dan Kebudayaan, (1995). Kamus Besar Bahasa Indonesia, Ed.II; Jakarta: Balai Pustaka, Hlm. 281, 255, 1048

${ }^{7}$ A.M. Hendroprioyono, Terorisme: Fundamentalis Kristen, Yahudi dan Islam (Jakarta: Buku Kompas, 2009), hlm. 13. sikap dan paham radikal. 1. Intoleran (tidak mau menghargai pendapat \& keyakinan orang lain), 2. Fanatik (selalu merasa benar sendiri; menganggap orang lain salah), 3. Eksklusif (membedakan diri dari umat Islam umumnya) dan 4. Revolusioner (cenderung menggunakan cara-cara kekerasan untuk mencapai tujuan).

Memiliki sikap dan pemahaman radikal saja tidak mesti menjadikan seseorang terjerumus dalam paham dan aksi terorisme. Ada faktor lain yang memotivasi seseorang bergabung dalam jaringan terorisme. Motivasi tersebut disebabkan oleh beberapa faktor. Pertama, Faktor domestik, yakni kondisi dalam negeri yang semisal kemiskinan, ketidakadilan atau merasa Kecewa dengan pemerintah. Kedua, faktor internasional, yakni pengaruh lingkungan luar negeri yang memberikan daya dorong tumbuhnya sentiment keagamaan seperti ketidakadilan global, politik luar negeri yg arogan, dan imperialisme modern negara adidaya. Ketiga, faktor kultural yang sangat terkait dengan pemahaman keagamaan yang dangkal dan penafsiran kitab suci yang sempit dan leksikal (harfiyah). Sikap dan pemahaman yang radikal dan dimotivasi oleh berbagai faktor di atas seringkali menjadikan seseorang 
memilih untuk bergabung dalam aksi dan jaringan terorisme.

Lalu apa itu terorisme? Banyak ragam pengertian dalam mendefinisikan terorisme. Dari beragam definisi baik oleh para pakar dan ilmuwan maupun yang dijadikan dasar oleh suatu negara, setidaknya memuat tiga hal: pertama, metode, yakni menggunakan kekerasan; kedua, target, yakni korban warga sipil secara acak, dan ketiga tujuan, yakni untuk menebar rasa takut dan untuk kepentingan perubahan sosial politik. ${ }^{8}$ Karena itulah, definisi yang dijadikan dasar oleh negara Indonesia dalam melihat terorisme pun tidak dilepaskan dari tiga komponen tersebut Dalam UU No.15 Tahun 2003 tentang Pemberantasan Tindak Pidana Terorisme disebutkan : Setiap orang yang dengan sengaja menggunakan kekerasan atau ancaman kekerasan menimbulkan situasi teror atau rasa takut terhadap orang secara meluas atau menimbulkan korban yang bersifat massal, dengan cara merampas harta benda orang lain, atau mengakibatkan kerusakan atau kehancuran terhadap obyek-oyek vital strategis atau

\footnotetext{
${ }^{8}$ Harvey W. Kushner, Encyclopedia of Terrorism, London : Sage Publication, 2003. Hlm. Xxiii.
}

lingkungan hidup atau fasilitas publik atau fasilitas internasional. ${ }^{9}$

\section{Radikalisme dan Terorisme di Jawa Timur Pasca-Reformasi}

Hingga saat ini, tidak sedikit orang yang masih gamang melihat masa depan Indonesia. Tidak jarang terdengan suara sumbang yang mempertanyakan apakah Indonesia sedang berjalan ke arah sebuah negara demokratis ataukah sebaliknya. Pesimisme ini tidak bisa diabaikan begitu saja, jika kita melihat berbagai peristiwa yang mengikuti Reformasi politik '98. Kekerasan dengan motif agama dan etnis merupakan fenomena mencolok yang menandai kehidupan sosial-politik keagamaan di Indonesia pasca-Soeharto (Suaedy, 2007 : 343). Jika satu wajah Reformasi ditunjukkan melalui tuntutan yang sangat kuat terhadap keterbukaan dan demokrasi, maka proses demokratisasi ini sejak dini telah mendapati dirinya berhadapan dengan ancaman yang serius, berupa konflik etnis dan agama (Sukma, 2005 : 1). Bisa dikatakan, pada saat yang masih sangat dini pascaReformasi, kekuatan demokratik telah menemukan dirinya bukanlah kekuatan dominan dalam peta politik Indonesia baru (Hefner, 2005).

\footnotetext{
9 Lihat UU No.15 Tahun 2003 tentang Pemberantasan Tindak Pidana Terorisme
} 
Situasi politik Indonesia pascaReformasi tidak hanya dipenuhi dengan persaingan antara kelompok prodemokrasi dengan sisa-sisa kekuatan politik rejim Orde Baru, tapi juga antara kelompok pro-demokrasi dengan kekuatan-kekuatan keagamaan dan etnis yang ingin mengambil untung dari situasi yang ada. Tidak ada yang menduga, bahwa chaos politik yang diakibatkan Reformasi melahirkan banyak kekerasan dengan jargon agama. Jika kekerasan komunal yang dipantik oleh sentimen agama dan etnis ini tidak bisa dipecahkan, tidak menutup kemungkinan, bahwa transisi demokrasi akan mengarah kepada otoritarianisme baru. Tuntutan implementasi syariat Islam oleh kelangan Islamis, misalnya, adalah suara lantang yang ingin menguasai ruang publik, dengan memanfaatkan nalar dan instrumen demokrasi yang baru seumur jagung ini, yang potensial untuk membalik arah demokrasi yang sedang dibangun. Misalnya, pada Agustus 2000, ribuan umat Islam datang ke Yogyakarta menghadiri Kongres Mujahidin untuk membentuk MMI (Majelis Mujahidin Indonesia). Dalam pidato sambutannya, Abu Bakar Ba'asyir, tokoh sentral gerakan ini, mengatakan bahwa hanya ada dua pilihan bagi umat Islam dalam rangka menegakkan syariat Islam di Indonesia: terlaksananya syariat Islam atau "kami akan mati sebagai sebagai seorang mujahid (Ba'asyir, 2001 : 139)."

Demokrasi juga dianggap sebagai halangan bagi pelaksanaan syariat Islam. Sebagaimana tercatat dalam rekomendasi Kongres Mujahidin, "Menolak demokrasi, republik, sistem dan bentuk pemerintahan yang merupakan produk doktrin kaum kafir, dan menyerukan kaum Muslim untuk menghidupkan kembali sistem pemerintahan syura dan bentuk negara khilafah (Awwas, 2001 : 158)." Lebih dari itu, jika selama ini Indonesia bangga sebagai pemeluk Islam terbesar di dunia dan menjadi kiblat dari kehidupan keislaman yang moderat, maka pascareformasi, radikalisme menjadi salah satu wajah Islam Indonesia. Bahkan, Indonesia telah menjadi bagian dari jaringan terorisme internasional. Sejak tahun 2000, berbagai bom meledak di beberapa wilayah Indonesia. Bom Bali 2002 yang membunuh ratusan orang, dan bom Mariot Jakarta 2003 yang membunuh belasan orang, semakin meyakinkan kesan, bahwa Indonesia telah masuk ke dalam front peperangan jaringan teroris internasional. Dari tahun 2008 sampai 2013, setidaknya ada lima kali kejadian bom bunuh diri yang 
dilakukan oleh orang-orang dari kelompok Muslim radikal (Hefner, 2005 : 274). Ketika pada pertengahan tahun 2014 dunia dibuat shock dengan berdirinya ISIS (Islamic State on Iraq and Siria), Indonesia yang telah menjadi bagian dari jaringan terorisme global juga mau tidak mau mendapat imbas dari fenomena ini.

Banyak Muslim Indonesia yang terang-terangan mendukung ISIS, bahkan terlibat dalam peperangan ISIS di Siria. Sebuah studi yang hendak mengukur efektifitas (dan kemungkinan kegagalan) gerakan demokrasi di Indonesia pasca-reformasi menyebutkan bahwa di negara plural seperti Indonesia, di mana sebagian besar persaingan politik didasari oleh sentiment etnis dan agama, maka luas partisipasi yangdibangun oleh satu kekuatan politik sangat potensial mengarah pada penciptaan pemerintahan terdesentralisasi yang nondemokratis. Ini bisa menjadi sisi gelap Reformasi politik Indonesia, di mana proses transisi tidak mengarah kepada terlembaganya demokrasi secara kokoh. Akan tetapi, tetap harus dipertimbangan keberadaan aktor-aktor prodemokrasi yang memiliki komitmen untuk tetap mencari alternatif, bahkan ketika jalan politik tampak buntu. Bahkan ketika konsosiasionalisme dipraktikkan, para aktor demokrasi tetap memiliki keinginan untuk melampaui golongan etnis dan agama dengan cara menahan gelombang dan mempromosikan bentuk-bentuk lain organisasi sosial politik (Prasetyo, Priyono \& Torrnquist, 2003 : xii-xiii).

\section{Lamongan dan Terorisme}

Indonesia sebagai salah satu negara yang dihuni oleh penduduk dengan mayoritas beragama Islam, menjadi sasaran sempurna dalam diskursus tindakan terorisme ini. Wacana tentang banyaknya jaringan dan gerakan Islam fundamental yang tumbuh dan berkembang di Indonesia menjadi salah satu indikator tersendiri dari tuduhan-tuduhan tersebut. Sikap dan tuduhan yang ditujukan kepada para penganut agama Islam ini sendiri bukan tanpa preseden.

Aksi terorisme berdalih agama adalah yang paling banyak terjadi di Indonesia dalam kurun satu setengah dekade terakhir. Tercatat kejadian mulai dari pengeboman yang terjadi di kedutaan besar Filipina di Jakarta pada 1 Agustus tahun 2000, Bom Bali I yang meledak di Paddy"s club pada 12 Oktober 2002 yang menyebabkan 202 jiwa melayang yang mayoritas berkewarganegaraan Australia. Aksi teror ini juga diikuti dengan teror-teror 
lainnya di tahun-tahun berikutnya, baik di Ibukota Jakarta seperti di Kedutaan besar Australia pada 9 September 2004, Hotel JW Marriot dan Ritz Charlton 17 Juli 2009, ataupun di daerah lainnya seperti Gereja Immanuel di Palu, Sulawesi Tengah pada 12 Desember 2004 dan Nyoman Kafe di Jimbaran Bali pada 1 Oktober 2005. Semua jejak rekam kasus pengeboman yang pernah terjadi di Indonesia tersebut menjadikan terorisme ini menjadi satu diskursus yang hangat di Indonesia, sekaligus menjadi stereotype bahwa Indonesia sebagai salah satu negara yang menjadi sarang perkembangan dan aksi terorisme (Akaha AZ 2002:43-49).

John Horgan menyatakan bahwa terjadi perubahan seorang atau sekelompok teroris dari orientasi kekerasan menuju non kekerasan karena transisi politik. Pada tahap berbeda mereka bisa kembali menjadi lebih radikal pada saat munculnya pulling factor solidaritas global atas adanya diskriminasi atau sebaliknya kekuatan kelompok transnasional dunia yang menguatkan ide, gagasan dan gerakan teroris di wilayah lain (Horgan, 2008). Radikalisme dan ektrimisme terjadi pada semua agama dan kelompok nasionalis. Gerakan teroris berkembang melalui peran aktor-aktor intelektual yang memberi landasan pemikiran strategis dan taktis dalam pergerakan teroris. Beberapa peristiwa pengeboman dan serangan terorisme di Indonesia dilakukan atas stimulasi dan pengaruh guidance dari para komandan teroris baik dilakukan secara tertutup melalui pengajian maupun terbuka melalui penerbitan, publikasi dan tulisan pendek di media online, blogging dan sosial media.

Penyerangan Thamrin Jakarta pada Januari 2016 adalah diantara aksi yang mendapat pengaruh kuat dari posting tulisan dari para komandan para pelaku. Adalah Bahrun Naim dan Aman Abdurrahman, dua tokoh ISIS Indonesia yang memengaruhi para pelaku dalam menjalankan aksi terorismenya. Para pelaku terpengaruh pada pemikiran Jihad, dan menjalankan instruksi yang dipublikasikan melalui media online dan media sosial. Pemikiran elit jihadis dan teroris berpengaruh kuat atas perkembangan dan pergerakan teroris. Kontra narasi dilakukan oleh pemerintah dan masyarakat sipil untuk membendung derasnya arus informasi radikal yang secara progresif dilakukan oleh ISIS. Pada tahap lebih kuat dan mengakar Jama'ah Islamiyah (JI) dan kelompok yang berafiliasi dengan AlQaidah telah melakukan pengaruh 
intelektual dan pemikiran ideologi jihadis melalui lembaga pendidikan, publikasi dan media yang lebih lama mereka kembangkan.

Sekitar tiga puluh sekolah yang berafiliasi dengan JI yang tersebar di Jawa Timur, Jawa Tengah, Jawa Barat, Jabodetabek, dan Indonesia Timur menjadi breeding grown efektif yang melahirkan generasi penerus jihadis (Magouirk dan Atran, 2008). Diantara mereka kemudian berafiliasi dengan ISIS, bahkan telah menjadi pelaku bom bunuh diri di Suriah. Wildan Mukhollad (lahir 6 Januari 1995) adalah salah satu mantan siswa di Pesantren Al-Islam Lamongan yang mendaftarkan sebagai sukarelawan bom bunuh diri ISIS di Suriah dan Irak. Wildan dipaksa orang tuanya untuk pindah dari Al-Islam Lamongan ke Al Azhar Mesir sekitar 2011 dengan tujuan untuk mengurangi ideologi jihadis yang dipelajari oleh Wildan di Pesantren AlIslam, tetapi Wildan menunjukkan respon lebih keras (Asad, 2014). Ketika ke Mesir, Wildan memiliki pemikiran dan peran lebih radikal dengan meninggalkan bangku sekolah dan bergabung dalam medan perang di Suriah melawan rejim Bashar Al-Asad. Pada pertengahan 2012 Wildan berangkat ke Aleppo bergabung dengan kelompok jihadis. Ketika AlBaghdadi mendeklarasikan diri menjadi
Khalifah, Wildan termasuk diantara yang bergabung. Pada awal Februari 2014 menyeberang ke Irak untuk menjadi pelaku bom bunuh diri ISIS. Di Irak, Wildan dikenal dengan nama Abu Bakar Al-Muhajir Al-Wildan Mukhollad bin Lasmin (Damanik, 2014).

Dari Intoleran dan Radikalisme hingga menjadi Terorisme

Nilai Budaya dan Praktik Sosial

Di lapisan dasar, nilai budaya dan praktik sosial berperan dalam menghasilkan kecenderungan toleran/intoleran dan radikal. Praktik toleransi/intoleransi dan radikalisme terkait dengan nilai dan praktik sosial yang ada di masyarakat. Apa yang diyakini oleh individu-individu di masyarakat dapat dipahami sebagai representasi sosial, sebagai ide dan keyakinan yang ada di masyarakat, yang diinternalisasi oleh individu. Representasi sosial adalah sekumpulan nilai, ide, metafora, keyakinan, dan praktik yang dibagi bersama di antara anggota kelompok dan komunitas (Moscovici, 1973).

Representasi sosial itu memungkinkan orang-orang dalam satu kelompok atau komunitas berbicara satu sama lain dan bertindak bersama serta saling berinteraksi. Itu menjadi seperangkat pengertian bersama dan 
memandu praktik sosial. Sistem nilai, ide dan praktik itu memiliki dua fungsi. Pertama, menegakkan keteraturan yang akan memampukan individu mengorientasikan dirinya dalam dunia material dan sosial, serta memampukannya melakukan penyesuaian diri dan penanganan lingkungan. Kedua, memungkinkan komunikasi mengenai beragam aspek dunia, individu dan kelompok berlangsung di antara anggota komunitas dengan menyediakan bagi peserta komunikasi kode untuk pertukaran sosial, penamaan dan klasifikasi secara jelas. Makna dikreasi melalui sistem negosiasi sosial ketimbang hal yang sudah ajek dan terdefinisikan. Penafsirannya mensyaratkan pengertian atas aspek tambahan dari lingkungan sosial.

\section{Kondisi Perekonomian}

Di lapisan berikutnya, kondisi perekonomian berperan dalam menghasilkan kecenderungan toleran/intoleran dan radikal. Kondisi perekonomian yang meleluasakan warga mengambil peranan dan memperoleh sumber daya memadai atau relatif merata, disertai ketimpangan ekonomi relatif rendah, mencegah timbulnya kecenderungan intoleransi dan radikalisme.

\section{Keragaman Sumber Norma}

Di lapisan berikutnya ditemukan faktor keragaman sumber norma ikut berperan dalam kecenderungan tolerasnsi/intoleransi dan radikalisme. Masyarakat yang hanya berpegang pada satu atau sedikit sumber norma menampilkan kecenderungan intoleran yang lebih tinggi, dari pada masyarakat yang mengandalkan banyak sumber norma. Namun perlu ditegaskan pula, beragam sumber norma itu harus memiliki hubungan positif atau kesesuaian antara satu dan lainnya, jika tidak maka bisa terjadi kebingungan pada warganya, untuk mengikuti norma yang mana dalam kehidupannya seharihari.

\section{Pengaruh Tokoh Signifikan}

Di lapisan berikutnya, faktor pengaruh tokoh yang signifikan dan dianggap penting oleh warga turut berperan terhadap kecenderungan toleran/intoleran dan radikalisme.

\section{Kehadiran dan Keberfungsian Negara}

Di lapisan paling atas, kehadiran dan keberfungsian negara berperan sebagai faktor penting dalam kecenderungan toleran/intoleran dan radikalisme. Di Kabupaten Lamongan yang diteliti ditemukan peran kehadiran dan keberfungsian negara dalam gejala toleran/intoleansi dan radikalisme. 
Peran negara yang diwakili pemerintah daerah dapat meningkatkan atau menurunkan gejala intoleransi dan radikalisme. Jika negara hadir dan menjalankan fungsi-fungsi yang efektif dan menjaga toleransi, maka kcederungan toleran pada warga akan lebih besar. Peran negara yang dimaksud di sini adalah berikap netral dan tegas, bekerja sesuai payung hokum yang tidak diskriminatif, antisipatif dengan menyiapkan semacam sistem peringatan dini (Early Warning System) kepada warga, untuk menghindar dari kecenderungan intoleran dan radikal, serta mampu memediasi dan koordinasi. Gejala toleransi/intoleransi dan radikalisme disebabkan oleh lebih dari satu faktor yang secara bersama-sama bekerja. Dalam pencermatan terhadap empat kota yang diteliti, semua faktor itu bekerja bersama-sama dalam porsi tertentu dalam menghasilkan kecenderungan tolerans/intoleransi dan radikalisme. Skema berikut ini meringkas faktor-faktor yang sudah dipaparkan di atas.

Intoleran didefinisikan sebagai ketidaksediaan atau ketidakmauan untuk memberikan hak pada orang atau kelompok yang berbeda, baik berbeda dalam keyakinan, ideologi, status sosial, maupun etnik. Sedangkan radikalisme adalah keyakinan seseorang yang begitu tinggi terhadap satu faham atau nilai, yang membuat ia menutup kemungkinan benar faham-faham lain, disertai dengan pandangan bahwa yang lain salah, sehingga layak diabaikan, dihilangkan atau dihukum. Radikalisme juga dipahami sebagai intoleransi dalam bentuk ekstrem, disertai dengan kecenderungan untuk menggunakan kekerasan, yang ditujukan kepada orang atau kelompok yang berbeda faham. Berdasarkan pengertian-pengertian ini, dan hasil studi di Kabupaten Lamongan yang diteliti, dibangun satu model penjelasan mengenai toleransi/intoleransi, radikalisme hingga terorisme.

Model ini menjelaskan hubungan antara perbedaan keyakinan dan toleransi/ intoleransi yang dimediasi oleh kepentingan ekonomi. Perbedaan keyakinan mempengaruhi toleransi/intoleransi bermuatan kepentingan ekonomi (termasuk juga kepentingan politik yang bertujuan memperoleh sumber daya ekonomi). Perbedaan keyakinan atau etnik saja tidak signifikan pengaruhnya terhadap toleransi/ intoleransi. Dalam berbagai kasus intoleransi selalu ada peran faktor ekonomi di dalamnya, yang menghubungkan perbedaan keyakinan 
atau etnik dengan intoleransi. Hubungan ini dimoderasi oleh kehadiran negara. Tingkat kehadiran negara yang tinggi memperkuat hubungan antara perbedaan dan toleransi, serta memperkuat hubungan antara perbedaan dan kepentingan ekonomi.

Nilai budaya dan praktik sosial berperan sebagai moderator dalam hubungan antara kepenting ekonomi dan toleransi/intoleransi, serta hubungan antara perbedaan dan toleransi/intoleransi. Seberapa kuat perbedaan menghasilkan kecenderungan toleransi/intoleransi ikut dipengaruhi oleh nilai budaya dan praktik sosial. Begitu juga seberapa kuat ketimpangan ekonomi mempengaruhi toleransi/intoleransi dipengaruhi oleh oleh nilai budaya dan praktik sosial. Radikalisme merupakan hasil pengaruh dari intoleransi. Semakin intoleran seseorang, semakin besar kemungkinannya untuk menjadi radikal. Tidak semua orang yang intoleran adalah orang yang radikal, tetapi semua orang yang radikal, dalam pengertian menggunakan kekerasan untuk menghadapi orang atau kelompok yang berbeda, adalah orang yang intoleran.

\section{Kesimpulan}

Hasil kajian di Kabupaten Lamongan ini memberikan pemahaman mengenai faktor apa saja yang secara signifikan mempengaruhi perspektif dan perilaku warga terkait perilaku intoleransi, radikalisme dan terorisme. Faktor yang berperan itu mencakup demografi, latar belakang budaya dan politik, affiliasi dan asosiasi, kebijakan, Nilai, Ideologi, makna agama, akses terhadap media sosial. Hubungan antara faktor-faktor toleransi/intoleransi dan radikalisme dapat dilihat berdasarkan letak faktor-faktor itu dalam lapisan sosial, mulai dari nilai yang tercakup dalam budaya hingga faktor struktural, yang mencakup kebijakan dan keberfungsian negara.

Di lapisan dasar, nilai budaya dan praktik sosial berperan dalam menghasilkan kecenderungan toleran/intoleran dan radikal. Di lapisan berikutnya, kondisi perekonomian berperan dalam menghasilkan kecenderungan toleran/intoleran dan radikal. Lalu, faktor keragaman sumber norma ikut berperan dalam kecenderungan toleransi/intoleransi dan radikalisme ada di lapisan berikutnya. Di lapisan berikutnya lagi, faktor pengaruh tokoh yang signifikan dan dianggap penting oleh warga turut berperan terhadap kecenderungan tolern/intoleran dan radikalisme. Di lapisan paling atas, kehadiran dan 
keberfungsian Negara berperan sebagai faktor penting dalam kecenderungan toleran/intoleran dan radikalisme.

Perbedaan keyakinan mempengaruhi toleransi/intoleransi bermuatan kepentingan ekonomi (termasuk juga kepentingan politik, yang bertujuan memperoleh sumber daya ekonomi). Perbedaan keyakinan atau etnik saja tidak signifikan pengaruhnya terhadap toleransi/intoleransi. Nilai budaya dan praktik sosial berperan sebagai moderator dalam hubungan antara kepenting ekonomi dan toleransi/intoleransi, serta hubungan antara perbedaan dan toleransi/intoleransi. Radikalisme merupakan hasil pengaruh dari intoleransi. Semakin intoleran seseorang, semakin besar kemungkinannya untuk menjadi radikal. Gejala toleransi/intoleransi dan radikalisme memiliki lebih dari satu sebab (multicausal). Seperti gejala sosial pada umumnya, tidak ada penyebab tunggal dari toleransi/intoleransi. Meskipun demikian, berdasarkan model yang dihasilkan studi ini, ada faktor yang dapat dikenali sebagai faktor yang mendahului yang lain.

\section{Daftar Pustaka}

Azca, Muhammad Najib. 2013. Yang Muda, Yang Radikal: Refleksi Sosiologis Terhadap Fenomena Radikalisme Kaum Muda Muslim di Indonesia Pasca Orde Baru\| Jurnal Maarif, Vol. 8, No. 1 (Juli 2013): $14-41$.

Cavatorta, Francesco. 2005. The =War on Terrorism'-Perspectives from Radical Islamic Groups. Journal of Irish Studies in International Affairs, Vol. 16 (2005). Diakses dari

http://doras.dcu.ie/488/1/isia 1

6 April 2017.pdf

Departemen Pendidikan dan Kebudayaan, 1995. Kamus Besar Bahasa Indonesia, Ed.II; Jakarta: Balai Pustaka.

Fadjar, Abdullah dkk, 2007. Laporan Penelitian Islam Kampus. Jakarta:Ditjen Dikti Depdiknas.

Kushner, Harvey W. 2003. Encyclopedia of Terrorism, London : Sage Publication.

Marsh, David dan Gerry Stoker. 2002. Theory and Methods in Politial Science. Hampshire: Palgrave Macmilla.

Moleong, Lexy J. 2004 . Metodologi Penelitian Kualitatif. Bandung: PT Remaja Rosdakarya. 
Peninjauan kembali Pendidikan Agama Islam. Dalam www.swattonline.com/2017/04/lakippemerintah-harus-tinjaukembalipendidikan-agama-islam $/ \mathrm{di}$ akses 10/04/2017 20:30 WIB

Rubaidi, A. 2010. Radikalisme Islam, Nahdlatul Ulama; Masa Depan Moderatisme Islam di Indonesia. Yogykarta: Logung Pustaka.

Terorisme di Indonesia, 2017. http://id.wikipedia.org/wiki/Ter orisme di Indonesia, diakses 20/04/2017, 20:39 WIB

U.S. Department of Justice, Hate Crime: The Violence of Intolerance, http://www. usdoj. gov/crs/pubs/htecrm.htm, diakses pada 1 Mei 2017, 22:04 WIB 